\title{
Transforming Growth Factor- $\alpha$ and Epidermal Growth Factor Expression in Human Fetal Gastrointestinal Tract
}

\author{
PÄIVI J. MIETTINEN \\ Department of Pathology and 1st Department of Pediatrics, University of Helsinki, SF-00290 Helsinki, Finland
}

\begin{abstract}
Epidermal growth factor (EGF) and transforming growth factor- $\alpha$ (TGF- $\alpha$ ) are mitogenic to the intestinal epithelium. To further clarify their role in the developing human fetal gut, their expression was studied in fetuses at 15 to 20 wk of gestation. TGF- $\alpha$ mRNA was present throughout the gastrointestinal tract, most abundantly in the duodenum. EGF mRNA could be detected only with ribonuclease protection assay and reverse transcription-polymerase chain reaction analysis. The effect of EGF and TGF- $\alpha$ on TGF- $\alpha$ mRNA expression was studied by culturing explants of fetal jejunum, ileum, and colon for $7 \mathrm{~d}$ in Leibowitz L-15 medium supplemented with $100 \mu \mathrm{g} /$ $L$ of either EGF or TGF- $\alpha$. EGF receptor-like immunoreactivity was detected in both the villi and the crypts. In the jejunum, exogenous EGF up-regulated TGF- $\alpha$ mRNA 3-fold. However, exogenous TGF- $\alpha$ reduced its own mRNA by $40 \%$. No mature 6-kD TGF- $\alpha$ was detected in the culture medium by Western blotting, but precursor forms of approximately 30 and $68 \mathrm{kD}$ were present. The ileum and colon did not respond to either growth factor. Besides the gut, TGF- $\alpha$ was expressed in the gallbladder, salivary gland, adrenals, brain, kidney, liver, and placenta. The data imply an important role for TGF- $\alpha$ and EGF in the developing intestine. (Pediatr Res 33: 481-486, 1993)
\end{abstract}

\section{Abbreviations}

EGF, epidermal growth factor

EGF-R, epidermal growth factor receptor

GI, gastrointestinal

TGF $-\alpha$, transforming growth factor $-\alpha$

PCR, polymerase chain reaction

AP, alkaline phosphatase

RNase, ribonuclease

EGF and TGF- $\alpha$ are mitogenic peptides that also inhibit gastric acid production $(1,2)$. In dogs, TGF- $\alpha$ is synthesized by parietal cells of the stomach (3). Many GI tumors (4) and cell lines as well as the normal human adult colon (5) synthesize TGF- $\alpha$ mRNA. Immunoreactive TGF- $\alpha$ has been detected in mucosal cells of human fetal (6) and adult (7) gut and in colorectal neoplasia (8). Rat intestinal epithelial cell line IEC-6 also expresses TGF- $\alpha$ transcripts and an EGF-R binding substance (9).

EGF is present in salivary, gastric, duodenal, pancreatic, and amniotic fluids (10). Immunohistochemically, EGF has been

Received August 20, 1992; accepted November 3, 1992

Correspondence and reprint requests: Päivi J. Miettinen, Department of Pathology and 1st Department of Pediatrics, University of Helsinki, SF-00290 Helsinki, Finland.

Supported by grants from the Pediatric Research Foundation, the Sigrid Juselius Foundation, and the Ahokas Foundation. found in human fetal $(6,11)$ and adult (12) intestine. In fetal rhesus monkey (13) and suckling rabbits (14), EGF stimulates proliferation of the intestinal epithelium. However, in fetal mice (15) and newborn rats (16), it has no effect on DNA synthesis. Therefore, the effects of EGF on small intestinal cell proliferation and maturation seem to vary with the developmental stage (17). In cultured human fetal jejunal explants, EGF increases lactase production and decreases DNA synthesis (17). DNA synthesis is also diminished by EGF in human fetal colon explants (18).

EGF-R binds both EGF and TGF- $\alpha$. Binding studies with ${ }^{125} \mathrm{I}-$ EGF show that in the human fetus EGF-R is present in the epithelial cells of both the small intestine and colon from the 12 th wk of gestation (19). Immunoreactive EGF-R is detectable in the villous epithelial cells from the 16th wk of gestation (20).

EGF up-regulates TGF- $\alpha$ mRNA in human colon carcinoma (21) and in rat intestinal epithelial cell lines (22) during 2 to 48 h of exposure. However, for a study of intestinal development, a longer stimulation time is needed to mimic the in vivo situation in utero with continuous passage of amniotic fluid through the fetal gut. The present study was undertaken to clarify the expression and role of EGF and TGF- $\alpha$ in the developing human fetal GI tract. It also explores whether these peptides regulate TGF- $\alpha$ mRNA production in long-term organ explant cultures.

\section{MATERIALS AND METHODS}

Fetal tissues. Tissues were obtained from prostaglandin-induced legal abortions at 15 to $20 \mathrm{wk}$ of gestation. The study was approved by the Ethical Committee of the Hospital. Delay from delivery room to liquid nitrogen or cell culture was $1 \mathrm{~h}$. The gestational age was estimated from the fetal foot length (23). The intestines were dissected from the surrounding mesentery and stored in liquid nitrogen at $-70^{\circ} \mathrm{C}$ for RNA extraction or further processed for organ explant cultures. Other tissues (submandibular salivary gland, pancreas, gallbladder, liver, adrenals, kidney, lungs, thyroid gland, brain, cerebellum, spinal cord, skin, testes, femur, and decidua from a 2nd-trimester placenta) were stored similarly.

Organ explant cultures. The intestine was divided into jejunum, ileum, and colon. These fragments were split longitudinally, cut into $3 \times 7 \mathrm{~mm}$ pieces, and placed in Petri dishes on lens papers (24). Explants were cultured overnight in (medium Dulbecco's minimum essential medium-10\% FCS-penicillinstreptomycin) and starved for $4 \mathrm{~h}$ in Leibowitz L-15 medium (Gibco, Paisley, UK) before stimulations with recombinant human EGF $100 \mu \mathrm{g} / \mathrm{L}$ (Bachem, Bubendorf, Switzerland) and recombinant human TGF- $\alpha 100 \mu \mathrm{g} / \mathrm{L}$ (Bachem) in Leibowitz L15 medium. The media were renewed after $d 1$ of culture and then every $2 \mathrm{~d}$. The explants were grown for $7 \mathrm{~d}$ and then processed for RNA extraction or immunohistochemistry. The morphology was preserved sufficiently after $7 \mathrm{~d}$ of culture and intense staining with hematoxylin was localized to the crypts.

RNA extraction and Northern analysis. Total cellular RNA 
A

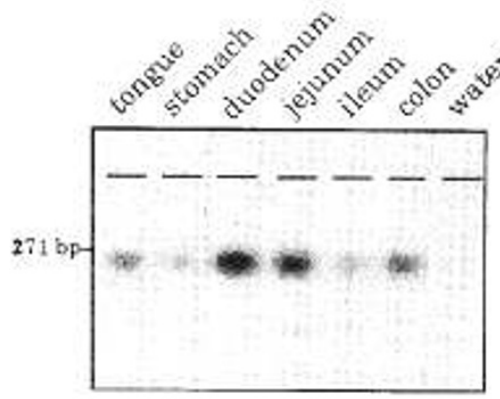

cultured jejunum

cultured ileum
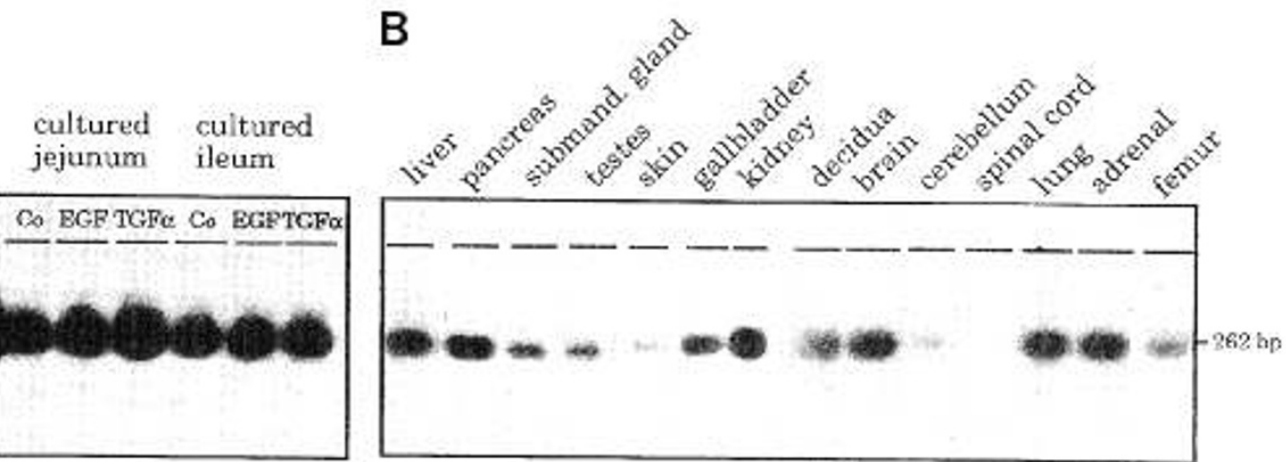

Fig. 1. Southern blots from TGF- $\alpha$ PCR. Reverse transcribed RNA from human fetal ( 15 to 20 wk of gestation) intact ( 30 cycles) and cultured $(60$ cycles) gut $(A)$ and other fetal tissues ( 30 cycles; $B$ ) were amplified using TGF- $\alpha$-specific primers. Autoradiography after Southern transfer and hybridization with a ${ }^{32} \mathrm{P}$-labeled TGF- $\alpha$ cDNA probe showed a single band of $262 \mathrm{bp}$. On the left is shown a 271 -bp band from the size marker IXRF174/HaeIII. The cultured intestine was grown in medium without (Co, control) or with supplementation of EGF or TGF- $\alpha$ (100 $\mu \mathrm{g} / \mathrm{L}$ both),

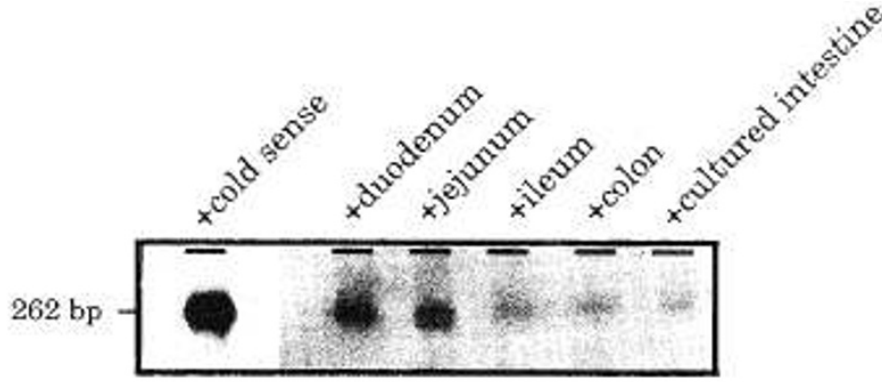

Fig. 2. RNase protection assay from intact and cultured human fetal gut. Fifty $\mu \mathrm{g}$ of RNA from fractioned intestine (17 wk of gestation) and $30 \mu \mathrm{g}$ RNA from cultured intestine were hybridized with a ${ }^{32} \mathrm{P}$-labeled TGF- $\alpha$ cRNA. After RNase treatment, 262-bp-protected fragments were obtained. A cold TGF- $\alpha$ cRNA sense strand was used as a positive hybridization control.

was isolated by guanidine isothiocyanate extraction and cesium chloride centrifugation (25), measured spectrophotometrically at $260 \mathrm{~nm}$, and stored at $-20^{\circ} \mathrm{C}$ until use. From a few tissues (fetal adrenal, brain, and placenta), polyadenylated RNA also was isolated using oligo(dT) columns (Pharmacia, Uppsala, Sweden).
RNA derived from A431 cells was used as a positive hybridization control for the TGF- $\alpha$ probe (4).

Ten to $30 \mu \mathrm{g}$ of total RNA (occasionally 2 to $8 \mu \mathrm{g}$ polyadenylated RNA) were denatured in glyoxal and DMSO and loaded into a $1.5 \%$ agarose gel (26). After electrophoresis, the RNA was transferred to a Hybond- $\mathrm{N}$ filter (Amersham, Buckinghamshire, UK) by capillary blotting. The filters were hybridized with EGF or TGF- $\alpha$ cRNA and $28 \mathrm{~S}$ or $\gamma$-actin cDNA probes as described (27). The filters were washed in $0.1 \times$ SSC $(1 \times$ SSC is $0.15 \mathrm{M}$ $\mathrm{NaCl}$ and $0.015 \mathrm{M}$ sodium citrate) with $0.1 \% \mathrm{SDS}$ (three times for $20 \mathrm{~min}$ at $65^{\circ} \mathrm{C}$ for cRNA and at $50^{\circ} \mathrm{C}$ for cDNA probes) and subjected to autoradiography using Trimax T16 (3M, Ferrania, Italy) intensifying screens and Hyperfilm MP films (Amersham) for 1 to $4 \mathrm{wk}$ at $-70^{\circ} \mathrm{C}$. Northern blots were usually done from three to six fetuses.

Dot blot. Total RNA (2.5 to $5 \mu \mathrm{g})$ was denatured in formaldehyde at $60^{\circ} \mathrm{C}$ for $15 \mathrm{~min}$ and blotted as described (26). The filters were hybridized as mentioned above. The signals obtained were scanned densitometrically. TGF- $\alpha$ readings were correlated with $28 \mathrm{~S}$ readings. Results are expressed as mean \pm SEM of four to five explant cultures (from four to five different fetuses).

Probes. A 925-bp EcoRI fragment of human TGF- $\alpha$ (28) and a 555-bp EcoRI fragment of human EGF (29) cDNA were subcloned into pGEM7 $(\mathrm{z})$ ribovectors (Promega Biotechnology,

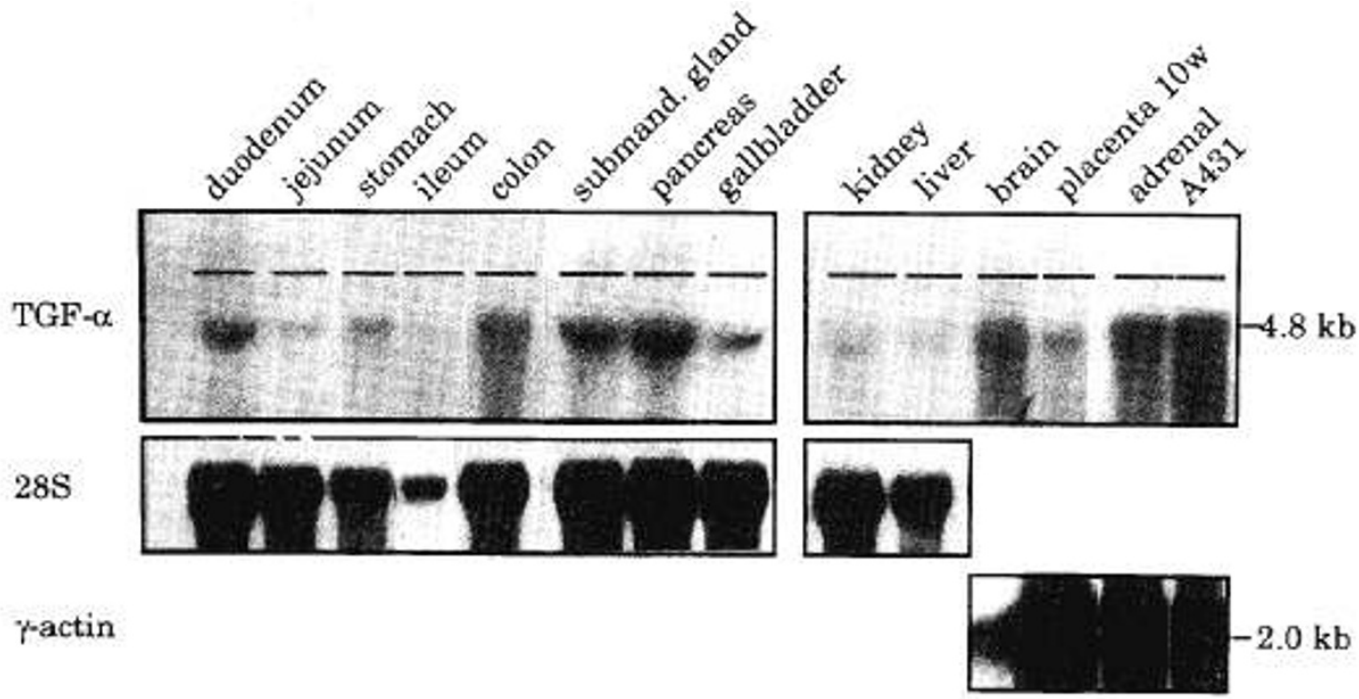

Fig. 3. Northern blot analysis of TGF- $\alpha$ expression in human fetus. Total RNA (30 $\mu \mathrm{g})$ from the human fetal GI tract and other tissues $(2-5 \mu \mathrm{g}$ polyadenylated RNA from brain, placenta, adrenals, and A431 cells) were subjected to electrophoresis and subsequently blotted onto a nylon filter and hybridized with a ${ }^{32} \mathrm{P}$-labeled TGF- $\alpha$ cRNA probe. The correct transcript size is shown on the right. Integrity of RNA samples was controlled with a $28 \mathrm{~S}$ or a $\gamma$-actin (polyadenylated RNA samples) cDNA probe. RNA derived from A431 cells was used as a positive hybridization control for the TGF- $\alpha$ probe. 


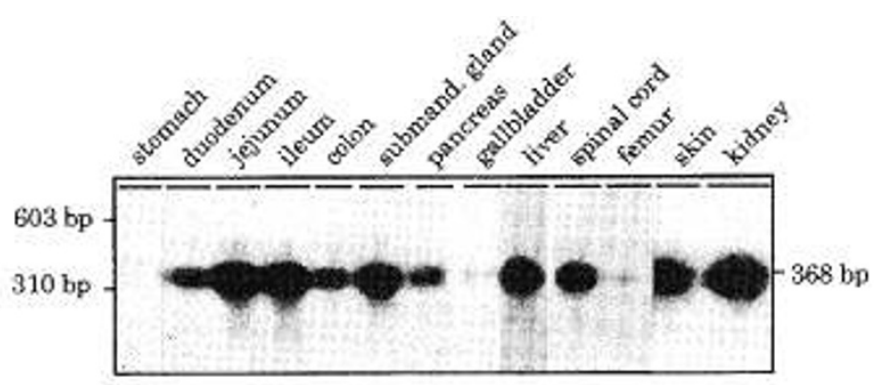

Fig. 4. Southern blots from EGF PCR. Reverse transcribed RNA from human fetal tissues (15 to 20 wk of gestation) was amplified using EGF-specific primers ( 30 cycles). Autoradiography after Southern transfer and hybridization with a ${ }^{32} \mathrm{P}$-labeled EGF oligoprobe produced a 368$\mathrm{bp}$ band. On the left are shown size markers from $\Phi$ X174RF/HaeIII.

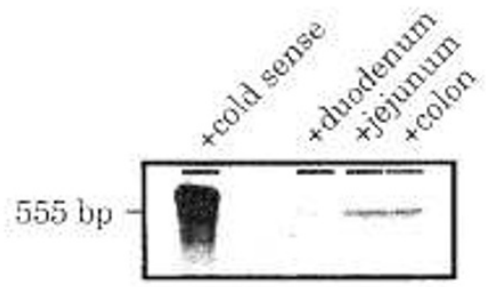

Fig. 5. RNase protection assay from intact and cultured human fetal gut. Fifty $\mu \mathrm{g}$ of RNA from human fractioned intestine (17 wk of gestation) was hybridized with a ${ }^{32} \mathrm{P}$-labeled EGF cRNA. After RNase treatment, 555-bp-protected fragments were obtained. A cold EGF cRNA sense strand was used as a positive hybridization control.

Madison, WI) and labeled with $\left[{ }^{32} \mathrm{P}\right]-\mathrm{UTP}(1000 \mathrm{Ci} / \mathrm{mmol}$, Amersham) by in vitro transcription using SP6 or T7 RNA polymerases (30). The correct size of the labeled probes was checked in a sequencing gel. TGF- $\alpha$ PCR fragments from human fetal decidua (1st trimester) and fetal duodenum (2nd trimester) were also subcloned into pGEM7(z) ribovectors as described (27). [ $\left.{ }^{32} \mathrm{P}\right]-\mathrm{dCTP}$ random prime-labeled (Oligolabeling Kit, Pharmacia, Uppsala, Sweden) $28 \mathrm{~S}$ or $\gamma$-actin cDNA (31) were used to verify the integrity of the RNA and to equalize the amounts of loaded RNA.

For PCR Southern blots, a ${ }^{32}$ P-labeled 925-bp TGF cDNA probe, a 27 -mer internal EGF oligoprobe (nucleotides 3440 to 3466 of human EGF precursor) (32), and a $\beta$-actin oligoprobe (nucleotides 312 to 338 of human $\beta$-actin cDNA) (33) were used for hybridizations. Oligoprobes were $3^{\prime}$-end-labeled with $\left[{ }^{32} \mathrm{P}\right]-$ dCTP using terminal transferase (DuPont/New England Nuclear labeling system, NEP-100, Boston, MA).

Reverse transcription and PCR. One $\mu \mathrm{g}$ of total RNA from each tissue was used for cDNA synthesis as described previously (34). For a negative control, water was used instead of RNA. PCR was performed according to the instructions provided with the GeneAmp DNA Amplification Reagent Kit (Perkin-ElmerCetus, Norwalk, CT). One $\mu \mathrm{L}$ of reverse transcription mixture was combined with 1 ) $5 \mu \mathrm{L}$ of $10 \times$ PCR-reaction buffer; 2) 37 $\mu \mathrm{L}$ of water; 3) $4 \mu \mathrm{L}$ of dNTP mixture $(0.2 \mu \mathrm{M}$ final concentration for each deoxynucleotide); 4) $50 \mathrm{pmol}$ of antisense and sense strand primes each; and 5) $2.5 \mathrm{U}$ of AmpliTaq (Perkin-ElmerCetus) enzyme. The reactions were heated to $95^{\circ} \mathrm{C}$ for $2 \mathrm{~min}$ and then immediately cycled $\left(30\right.$ cycles: $94^{\circ} \mathrm{C}$ for $30 \mathrm{~s}$ for denaturation, $58^{\circ} \mathrm{C}$ for $30 \mathrm{~s}$ for annealing, and $72^{\circ} \mathrm{C}$ for $1 \mathrm{~min} 30 \mathrm{~s}$ for elongation) in a Hybaid thermal reactor (Teddington, UK).

The following oligonucleotide primers were synthesized: a 20 mer TGF- $\alpha$ sense primer ( $5^{\prime}$-CGCCCTGTTCGCTCTGGGTA$3^{\prime}$ ) corresponds to nucleotides 58 to 77 , and a 20 -mer antisense primer (5'-CTGGCTGGCAGCCACCACGG-3') corresponds to nucleotides 300 to 319 (35). The expected size of the TGF- $\alpha$ PCR product is 262 bp. EGF 20-mer sense (5'GACGCCTGTCTGAACCAGGA- $3^{\prime}$ ) and 20-mer antisense (5'CGATAGCAGCTTCTGAGTCC-3') primers create a 368-bp fragment corresponding to nucleotides 3261 to 3628 of the EGF precursor (32). $\beta$-Actin sense (5'-CCCAGGCACCAGGGCGTGAT-3'; nucleotides 153 to 172 ) and antisense (5'-TCAAACATGATCTGGGTCAT-3'; nucleotides 396 to 415 ) primers create a 263-bp fragment (33). The $\beta$-actin PCR was done to verify the integrity of the reverse transcribed mRNA.

Ten- $\mu \mathrm{L}$ aliquots of the PCR reaction products were sizefractionated in $2 \%$ agarose gel (Pharmacia, Sweden). HaelIIdigested pBR322/ XXRF fragments were used as size markers. Southern transfer was done by capillary blotting the DNA to Hybond- $\mathrm{N}$ nailon membranes (Amersham). The membranes were hybridized with ${ }^{32} \mathrm{P}-\mathrm{dCTP}$-labeled TGF- $\alpha$ cDNA, EGF, or $\beta$-actin oligoprobes.

$R$ Nase protection assay. Protection assay was performed as described (27). Briefly, 30 to $80 \mu \mathrm{g}$ of fetal RNA samples were hybridized with $200000 \mathrm{cpm}$ of ${ }^{32}$ P-labeled EGF and TGF- $\alpha$ riboprobes. Transfer RNA was used as a negative control and cold sense strands as positive controls. After treatments with RNaseA (40 mg/L; Sigma Chemical Co., MO) and RNaseT1 (375 $000 \mathrm{U} / \mathrm{L} ;$ Boehringer, Mannheim, Germany) and digestion with proteinase $\mathrm{K}(100 \mathrm{mg} / \mathrm{L})$ and $0.5 \% \mathrm{SDS}$, the protected RNA-RNA duplexes were extracted with phenol and chloroform, precipitated with ethanol, and analyzed on denaturing $6 \%$ PAGE-urea gel. The EGF riboprobe contained 555-bp bases of EGF mRNA and 30 bases of the pGEM7 $(\mathrm{z})$ sequence. The TGF$\alpha$ riboprobe contained 270 bases of TGF- $\alpha$ mRNA and 40 bases of the vector sequence, respectively.

Immunohistochemistry. Paraformaldehyde-fixed cultured jejunum, ileum, and colon explants were embedded in paraffin. Immunohistochemistry was performed using a Super Sensitive Multilink kit and a monoclonal EGF-R antibody (BioGenex, San Ramon, CA) (27). This antibody reacts with the $170-\mathrm{kD}$ EGF-R transmembrane glycoprotein (obtained from A431 carcinoma cells). Briefly, the sections were incubated for $1 \mathrm{~h}$ with the antibody, washed twice in PBS- $0.25 \%$ Triton X-100 (PBSTX), and incubated with biotinylated anti-immunoglobulins for $20 \mathrm{~min}$. The sections were then washed again in PBS-TX, and treated with AP-conjugated streptavidin for $20 \mathrm{~min}$ and with substrate solution for $25 \mathrm{~min}$. Endogenic AP was blocked by including $10 \mathrm{mM}$ levamisole (Sigma) and $25 \mathrm{mM}$ phenylalanine in the substrate solution. Fast Red was used as a chromogen. EGF-R antibody was replaced by normal mouse serum for specificity controls. To exclude false-positive staining due to endogenous AP, the immunostaining was also performed with peroxidase-conjugated streptavidin (Dako, Copenhagen, Denmark) instead of AP. The results were the same with both enzyme conjugates. Before microscopic examination, the slides were counterstained with Mayer's hematoxylin.

Western immunoblot analysis. Two-mL samples from d- 5 and d-7 intestine cultures were pooled, concentrated 40-fold with Centricon 3 (Grace \& Co, Beverly, MA), and mixed with $2 \times$ Laemmli buffer with $\beta$-mercaptoethanol. After $15 \%$ SDS-gel electrophoresis (36), the samples were electroblotted $(250 \mathrm{~mA}$ for $1 \mathrm{~h}$ ) to Hybond C-nitrocellulose paper (Amersham) using Bio-Rad Trans-Blot apparatus (37). Nonspecific binding was blocked by incubating the membrane overnight in $10 \%$ BSA$0.1 \%$ Tween 20 (Bio-Rad, Richmond, CA) in PBS. The membrane was incubated with the goat anti-human TGF- $\alpha(1: 15000$ dilution, Biotope), washed thoroughly in $0.1 \%$ Tween-PBS, and incubated with peroxidase-conjugated donkey anti-sheep IgG (Jackson, West Grove, PA). The immunoreaction was detected using the ECL system according to the manufacturer's instructions (Amersham). Recombinant TGF- $\alpha$ (Amgen) was used as a positive control. For specificity controls, staining was performed with preabsorbed antiserum (14 $\mu \mathrm{M}$ TGF- $\alpha$ ). Immunoreactions were either abolished or reduced.

\section{RESULTS}

Expression of $T G F-\alpha m R N A$ in intestine. Samples of total RNA from human fetal (15 to $20 \mathrm{wk}$ of gestation) duodenum, 
( $(\forall I$ '8!

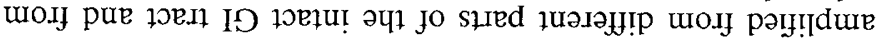

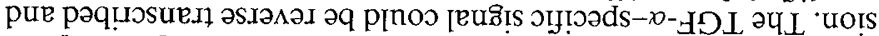

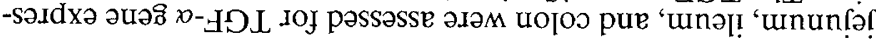

'ษә әчเ

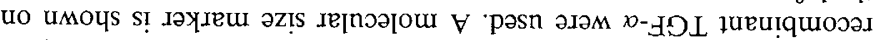

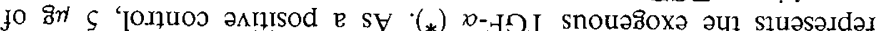

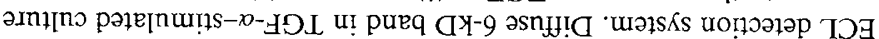

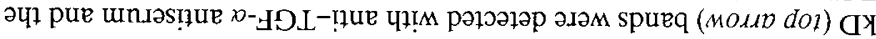

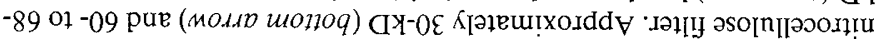

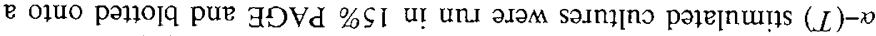
- HOl pue (G) -

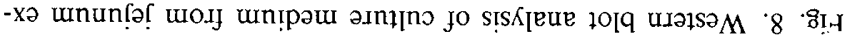

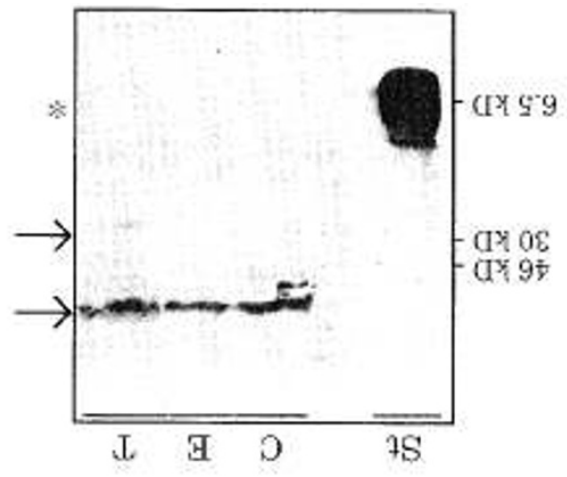

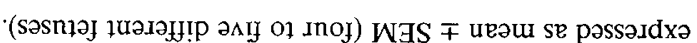

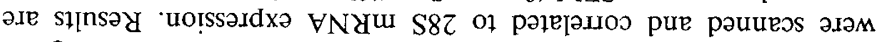

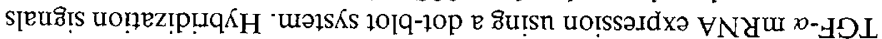

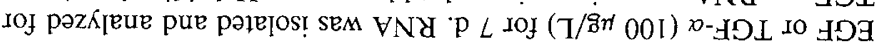

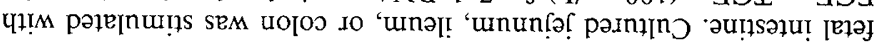

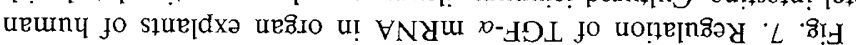
uojor unə!! ununtə?

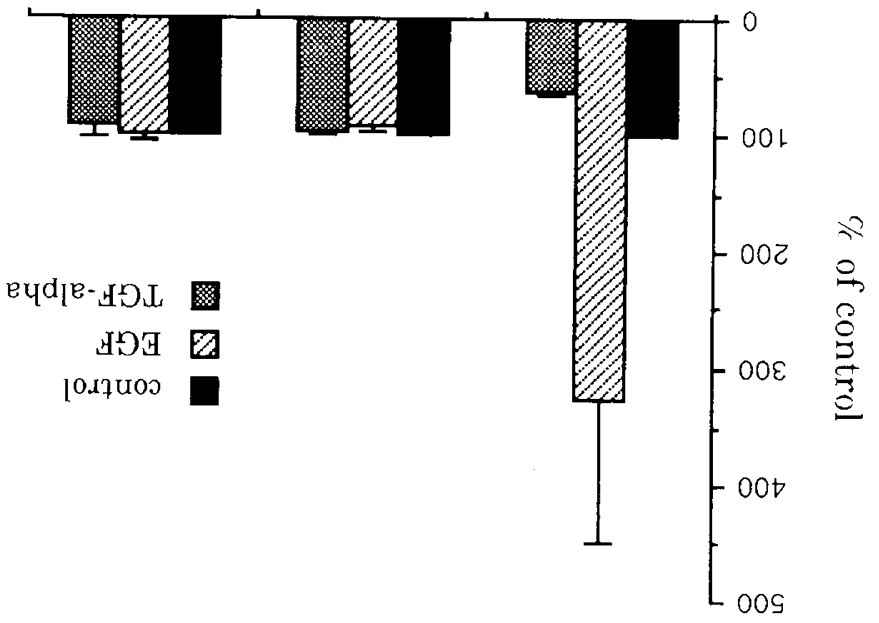

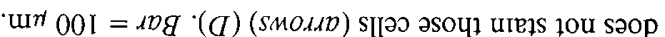

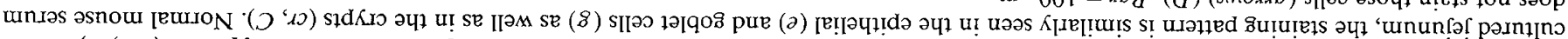

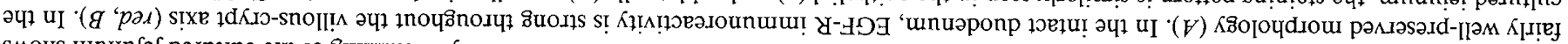

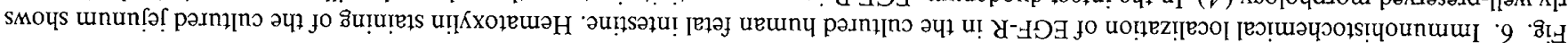
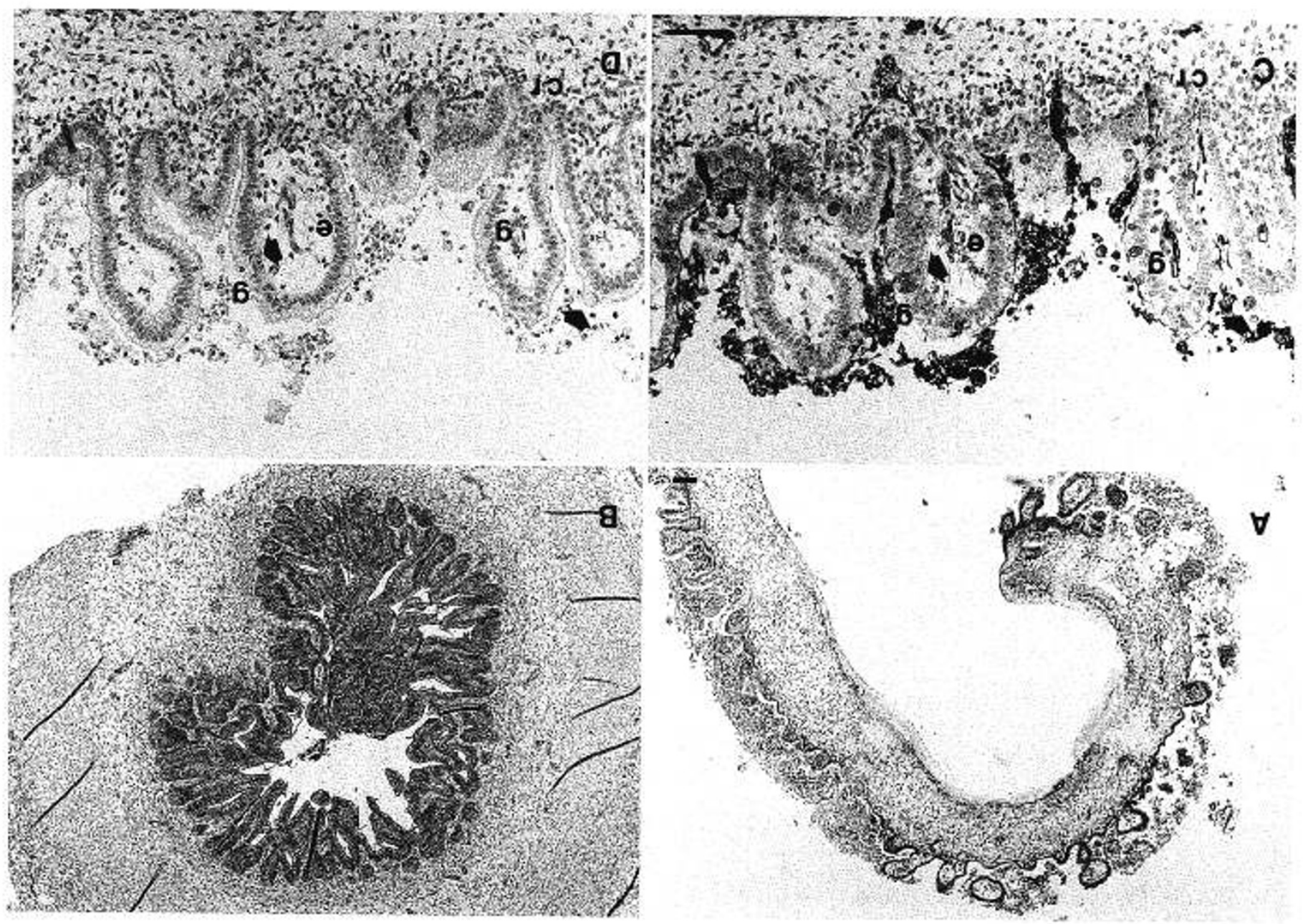
Other positive tissues were submandibular salivary gland, pancreas, gallbladder, liver, adrenals, kidney, lungs, thyroid gland, brain (cerebellum, weakly), spinal cord, skin, testes, femur (weakly), and decidua from a 2nd-trimester placenta (Fig. 1B). An RNase protection assay was performed using a TGF- $\alpha$ riboprobe obtained from a decidual TGF- $\alpha$ PCR fragment. Protected hybrids were seen in both the fractioned and the cultured intestine (Fig. 2). A single band of $4.8 \mathrm{~kb}$ corresponding to TGF- $\alpha$ mRNA was also detected by Northern blotting; it was strongest in the duodenum (Fig. 3). TGF- $\alpha$ mRNA was only faintly visible in cultured jejunal organ explants (data not shown). TGF- $\alpha$ expression was also detected with Northern blotting from submandibular salivary gland, gallbladder, pancreas, kidney, adrenal, brain, liver, and placenta (10 wk of gestation) (Fig. 3). The integrity of the RNA samples was controlled by hybridization with a $28 \mathrm{~S}$ or a $\gamma$-actin cDNA probe (not shown). RNA for PCR, RNase protection, and Northern blot analysis derived from different fetuses.

Expression of EGF $m R N A$ in intestine. An EGF-specific 367bp PCR fragment was amplifiable from duodenum, jejunum, ileum, and colon. Specificity was verified by hybridizing the generated Southern blots with an internal oligoprobe (Fig. 4). Other tissues positive in EGF PCR were skin, kidney, liver, submandibular salivary gland, pancreas, thyroid gland (not shown), and, faintly, femur (comprised also bone marrow; Fig. 4). The sensitivity of Northern blot analysis was insufficient to detect any EGF mRNA from the intestine. Using RNase protection assay, however, EGF transcripts could be located in duodenum, small intestine, and colon, respectively, corresponding to the PCR results (Fig. 5).

Regulation of TGF- $\alpha$ mRNA by EGF and TGF- $\alpha$ in intestine organ cultures. To further elucidate the function of EGF and $\mathrm{TGF}-\alpha$ in fetal gut, organ cultures were studied. Explants from the jejunum, ileum, and colon (five different fetuses of 15 to 19 wk of gestation) were grown in Leibowitz L-15 medium supplemented with EGF $(100 \mu \mathrm{g} / \mathrm{L})$ or TGF- $\alpha(100 \mu \mathrm{g} / \mathrm{L})$ for $1 \mathrm{wk}$. The presence of immunoreactive EGF-R in the intestine was demonstrated by an MAb against the extracellular domain of the receptor. In the intact small and large intestine, EGF-R-like immunoreactivity was detected in the crypts, villi (being strongest in the apical region and in the brush border, although also in the basolateral region of the epithelial cells), capillary vessel walls, and in lamina propria. In the cultured jejunum, EGF-R-like immunoreactivity was localized to the goblet cells and epithelial cells of the villi and to the crypts (Fig. 6). In the cultured ileum and colon, the villous epithelium was only weakly positive. Endogenous AP was blocked during the staining procedure by levamisole and phenylalanine (38). For specificity controls, the antibody was replaced with normal mouse serum, and no staining was then seen. Furthermore, identical staining patterns were obtained when a peroxidase-conjugated rabbit anti-mouse antiserum was used instead of an AP-conjugated antiserum (not shown). This precluded the possibility that the intense staining would represent endogenous AP.

Because the amount of RNA obtained from the cultures was too low for Northern blot analysis, the regulation of TGF- $\alpha$ mRNA was studied in a dot-blot system. In the jejunum, EGF up-regulated TGF- $\alpha$ mRNA by approximately 3-fold, but TGF$\alpha$ down-regulated its own mRNA by $40 \%$. The ileum and colon did not respond to either growth factor (Fig. 7). To study whether the TGF- $\alpha$ mRNA is translated to protein, Western blot analysis was performed from the concentrated culture media. No mature TGF- $\alpha$ peptide was detectable (apart from the exogenous TGF$\alpha$ ), but precursor forms of approximately $30 \mathrm{kD}$ and 60 to 68 $\mathrm{kD}$ were found (Fig. 8). When an antiserum preabsorbed with excess TGF- $\alpha$ was used, these immunoreactive bands were abolished. The amount of protein in the control and EGF/TGF- $\alpha-$ stimulated organ explants could not be equalized owing to limited material; therefore, no difference was seen between the control and stimulated cultures.

\section{DISCUSSION}

The present article reports the expression of EGF and TGF- $\alpha$ mRNA in the human fetal 2 nd-trimester GI tract. TGF- $\alpha$ expression was strongest in the duodenum, gallbladder, pancreas, and submandibular salivary gland. It was expressed more abundantly in the intestine than EGF, because EGF mRNA was detectable only with the sensitive PCR and RNase protection assays, but TGF- $\alpha$ mRNA was also demonstrated by Northern blot analysis. TGF- $\alpha$ is synthesized during early murine development (10), but from human fetuses there is little evidence of this (27). EGF mRNA has not been previously detected during fetal development, probably because of insensitivity of methods. Nevertheless, the present data reveal a low-level expression of EGF in the 2ndtrimester human fetal intestine. Thus, TGF- $\alpha$ appears to be the major EGF-like peptide in 15- to 20-wk-old human fetuses.

Human fetal jejunum and colon grow in organ culture $(39,40)$. At the 18th wk of gestation, proliferating epithelial cells in the cultured and intact intestine are confined to the crypts. In the present study, the morphology of the explant cultures was preserved after $7 \mathrm{~d}$ in culture, and staining with hematoxylin was localized to the crypts (Fig. $7 A$ ). Immunoreactive EGF-R was also strongly detected in the villi, crypts, and capillary vessel wall in both the intact and the cultured intestine (Fig. $7 B-C$ ). Furthermore, TGF- $\alpha$ mRNA was inducible with exogenous EGF. This agrees with previous results with adult human and animal cell cultures; namely, TGF- $\alpha$ mRNA was up-regulated by EGF and/or TGF- $\alpha$ (5 to $100 \mu \mathrm{g} / \mathrm{L})$ in most short-term (2- to $48-\mathrm{h})$ stimulation experiments with rat intestinal epithelial cells (22), regenerating liver (41), carcinoma cells from human pancreas (42), and cultured human keratinocytes (43). These effects were transient, usually declining within $24 \mathrm{~h}$. The mechanism behind the TGF- $\alpha$ mRNA rise may be increased transcription (44). In well-differentiated quiescent colon carcinoma cells, EGF also upregulated TGF- $\alpha$ mRNA, but was without effect on TGF- $\alpha$ synthesis in poorly differentiated cells $(21,45)$. In the present study, exogenous TGF- $\alpha$ reduced its own mRNA expression by $40 \%$. This differs from the above-mentioned reports on adult and malignant cells, probably owing to the longer observation time used in the present experiments. Why EGF and TGF- $\alpha$ have different effects on TGF- $\alpha$ mRNA remains unclear. Recently, TGF- $\alpha$ binding was found to be increased in a pancreatic cancer cell line at alkaline $\mathrm{pH}$. At neutral $\mathrm{pH}$, TGF- $\alpha$ binding was markedly less than EGF binding (46). Therefore, EGF and TGF- $\alpha$ may regulate signal transduction pathways differently in different cell types through dissimilar interactions with the receptor. In addition, the intestine may respond differently to different doses of EGF and TGF- $\alpha$. Unfortunately, the limited material available did not allow detailed dose-response studies.

Surprisingly, in the ileum and colon, TGF- $\alpha$ mRNA synthesis did not change after stimulations with EGF and TGF- $\alpha$. According to our Northern blot results, there are no substantial differences in TGF- $\alpha$ expression between the intact jejunum, ileum, and colon. However, we found previously that the ileum and colon contain less TGF- $\alpha$-like immunoreactivity than the duodenum and jejunum (6). Furthermore, it has been shown that, in fetal rhesus monkey, the growth-promoting activity of EGF is largely restricted to the upper intestine (13). Therefore, the 2ndtrimester ileum and colon may require higher concentrations of EGF/TGF- $\alpha$ than the jejunum to obtain similar effects. This could be due to a difference in receptor density. In autoradiographic studies, the human fetal colon exhibited more EGFbinding capacity than the small intestine (19). However, my unpublished results show that the EGF-R immunoreactivity is rather equally distributed between jejunum, ileum, and colon (two to three fetuses). In the present study, a strong EGF-R immunoreaction is located both in the crypts and in the brush border. The mapping of EGF-R to the apical surface is contrary to the ${ }^{125} \mathrm{I}-\mathrm{EGF}$ binding study of Menard and Pothier (47). Methodologic differences could explain the partially different 
results. Furthermore, the absence of labeled EGF in the villi observed by Menard and Pothier could also result from the already occupied EGF receptors by endogenous TGF- $\alpha$ or EGF.

EGF and TGF $\alpha$ are both mitogens. In the human fetal jejunum and colon, EGF stimulates proliferation and differentiation $(17,18)$. EGF also promotes proliferation of the small intestinal mucosa in neonatal microvillous atrophy (48). The present demonstration of expression of both TGF- $\alpha$ and EGF in the human fetal GI tract further implies an important role for these peptides in the developing gut. Introduction of EGF-like peptides into the treatment of very premature newborns may in the future help to prevent GI problems caused by the immature intestines of these babies.

Acknowledgments. The author thanks Dr. Graeham Bell for giving the EGF and TGF- $\alpha$ cDNA; Päivi Laitinen, Eija Teva, and Björn Lindroos for technical assistance; and Kari Sarkkinen for making the color photographs. I am grateful to Prof. Jaakko Perheentupa and Dr. Raimo Voutilainen for their valuable comments on the manuscript.

\section{REFERENCES}

1. Dembinski A, Drozdowicz D, Gregory H, Konturek SJ, Warzecha Z 1986 Inhibition of acid formation by epidermal growth factor in isolated rabbit gastric glands. J Physiol (Lond) 378:347-357

2. Rhodes JA, Tam JP, Finke U, Saunders M, Bernanke J, Silen W, Murphy RA 1986 Transforming growth factor $\alpha$ inhibits secretion of gastric acid. Proc Natl Acad Sci USA 83:3844-3846

3. Beauchamp RD, Barnard JA, McCutchen CM, Cherner JA, Coffey RJ 1989 Localization of transforming growth factor $\alpha$ and its receptor in gastric mucosal cells. Implications for a regulatory role in acid secretion and mucosal renewal. J Clin Invest 84:1017-1023

4. Derynck R, Goeddel DV, Ullrich A, Gutterman JU, Williams RD, Bringman TS, Berger WH 1987 Synthesis of messenger RNAs for transforming growth factors $\alpha$ and $\beta$ and the epidermal growth factor receptor by human tumors. Cancer Res 47:707-712

5. Malden LT, Novak U, Burgess AW 1989 Expression of transforming growth factor alpha messenger RNA in the normal and neoplastic gastrointestinal tract. Int J Cancer 43:380-384

6. Miettinen PJ, Perheentupa J, Otonkoski T, Lähteenmäki A, Panula P 1989 EGF- and TGF $\alpha$-like peptides in human fetal gut. Pediatr Res $26 \cdot 25-30$

7. Cartlidge SA, Elder JB 1989 Transforming growth factor $\alpha$ and epidermal growth factor levels in normal human gastrointestinal mucosa. $\mathrm{Br} \mathrm{J}$ Cancer 60:657-660

8. Tanaka S, Imanishi K, Yoshihara M, Haruma K, Sumii K, Kajiyama G, Akamatsu S 1991 Immunoreactive transforming growth factor alpha is commonly present in colorectal neoplasia. Am J Pathol 139:123-129

9. Koyama S-Y, Podolsky DK 1989 Differential expression of transforming growth factors $\alpha$ and $\beta$ in rat intestinal epithelial cells. J Clin Invest 83:17681773

10. Carpenter G, Wahl MI 1991 The epidermal growth factor family. In: Sporn MB, Roberts AB (eds) Peptide Growth Factors and Their Receptors I. Springer-Verlag, New York, pp 69-171

11. Poulsen S, Nexo E, Skov Olsen P, Hess J, Kirkegaard P 1986 Immunohistochemical localization of epidermal growth factor in rat and man. Histochemistry 85:389-394

12. Elder JB, Williams G, Lacey E, Gregory H 1978 Cellular localization of human urogastrone/epidermal growth factor. Nature 271:466-467

13. Read LC, Tarantal A, George-Nascimento C 1989 Effects of recombinant human epidermal growth factor on the intestinal growth of fetal rhesus monkey. Acta Paediatr Scand [Suppl]351:97-103

14. O'Loughlin EV, Chung M, Hollenberger M, Hayden J, Zahavi I, Gall DG 1985 Effect of epidermal growth factor on ontogeny of the gastrointestinal tract. Am J Physiol 249:G674-G678

15. Beaulieu JF, Ménard D, Calvert R 1985 Influence of epidermal growth factor on the maturation of the fetal mouse duodenum in organ culture. J Pediatr Gastroenterol Nutr 4:476-481

16. Foltzer-Jourdainne C, Raul F 1990 Effect of epidermal growth factor on the expression of digestive hydrolases in the jejunum and colon of newborn rats. Endocrinology 127:1763-1769

17. Ménard D, Arsenault P, Pothier P 1988 Biologic effects of epidermal growth factor in human fetal jejunum. Gastroenterology 94:656-663

18. Mênard D, Corriveau L, Arsenault P 1990 Differential effects of epidermal growth factor and hydrocortisone in human fetal colon. J Pediatr Gastroenterol Nutr 10:13-20

19. Pothier P, Ménard D 1988 Presence and characteristics of epidermal growth factor receptors in human fetal small intestine and colon. FEBS Lett 228:113-117
20. Oliver AM 1988 Epidermal growth factor receptor expression in human foetal tissues is age-dependent. $\mathrm{Br} \mathrm{J}$ Cancer 58:461-463

21. Mulder KM, Zhong Q, Choi HG, Humphrey LE, Brattain MG 1990 Inhibitory effects of transforming growth factor $\beta 1$ on mitogenic response, transforming growth factor $\alpha$ and c-myc in quiescent, well-differentiated colon carcinoma cells. Cancer Res 50:7581-7586

22. Suemori S, Ciacci C, Podolsky DK 1991 Regulation of transforming growth factor expression in rat intestinal epithelial cell lines. J Clin Invest 87:22162221

23. Munsick RA 1984 Human fetal extremity lengths in the interval from 9 to 21 menstrual weeks of pregnancy. Am J Obstet Gynecol 149:883-887

24. Ménard D, Arsenault P 1985 Explant culture of human fetal small intestine. Gastroenterology 88:691-700

25. Chirgwin JM, Przybyla AE, MacDonald RJ, Rutter WJ 1979 Isolation of biologically active ribonucleic acid from sources enriched in ribonuclease. Biochemistry 18:5294-5299

26. Voutilainen R, Tapanainen J, Chung B-C, Matteson KJ, Miller WL 1986 Hormonal regulation of $\mathrm{P} 450 \mathrm{scc}(20,22$-desmolase) and P450c17 (17 $\alpha$ hydroxylase/17, 20-lyase) in cultured human granulosa cells. J Clin Endocrinol Metab 63:202-207

27. Miettinen PJ, Heikinheimo K 1992 Transforming growth factor alpha and insulin gene expression in human fetal pancreas. Development 113:833-840

28. Murray JC, DeHaven CR, Bell GI 1986 RFLPs for epidermal growth factor (EGF), a single copy sequence at 4q25-4q27. Nucleic Acids Res 14:5117

29. Murray JC, Buetow KH, Bell GI 1986 RFLPs for transforming growth factor alpha (TGFA) gene at 2p13. Nucleic Acids Res 14:7126

30. Melton DA, Krieg PA, Rebagliati MR, Maniatis T, Zinn K, Green MR 1984 Efficient in vitro synthesis of biologically active RNA and RNA hybridization probes from plasmids containing a bacteriophage SP6 promoter. Nucleic Acids Res 12:7035-7056

31. Arnheim N 1979 Characterization of mouse ribosomal gene fragments purified by molecular cloning. Gene 7:83-96

32. Bell GI, Fong NM, Stempien MM, Wormsted MA, Caput D, Ku L, Urdea MS, Rall LB, Sanchez-Pescador R 1986 Human epidermal growth factor precursor: cDNA sequence, expression in vitro and gene organization. Nucleic Acids Res 14:8427-8446

33. Ponte P, Ng S-Y, Engel J, Gunning P, Kedes L 1984 Evolutionary conservation in the untranslated regions of actin mRNAs: DNA sequence of a human beta-actin cDNA. Nucleic Acids Res 12:1687-1696

34. Voutilainen R, Ilvesmäki V, Miettinen PJ 1991 Low expression of $3 \beta$-hydroxy5 -ene steroid dehydrogenase gene in human fetal adrenals in vivo; adrenocorticotropin and protein kinase C-dependent regulation in adrenocortical cultures. J Clin Endocrinol Metab 72:761-767

35. Derynck R, Roberts AB, Winkler ME, Chen EY, Goeddel DV 1984 Human transforming growth factor- $\alpha$ : precursor structure and expression in $E$. coli. Cell 38:287-297

36. Laemmli UK 1970 Cleavage of structural proteins during the assembly of the head of bacteriophage T4. Nature 227:680-685

37. Towbin H, Staehelin T, Gordon J 1979 Electrophoretic transfer of proteins from polyacrylamide gels to nitrocellulose sheets: procedure and some applications. Proc Natl Acad Sci USA 76:4350-4354

38. Ménard D, Pothier P 1987 Differential distribution of digestive enzymes in isolated epithelial cells from developing human fetal small intestine and colon. J Pediatr Gastroenterol Nutr 6:509-516

39. Arsenault P, Ménard D 1987 Cell proliferation in developing human jejunum. Biol Neonate 51:297-304

40. Arsenault P, Menard D 1989 Cell proliferation during morphogenesis of the human colon. Biol Neonate 55:137-142

41. Mead JE, Fausto N 1989 Transforming growth factor $\alpha$ may be a physiological regulator of liver regeneration by means of an autocrine mechanism. Proc Natl Acad Sci USA 86:1558-1562

42. Glinsmann-Gibson BJ, Korc M 1991 Regulation of transforming growth factor- $\alpha$ mRNA expression in $\mathrm{T}_{3} \mathrm{~T}_{4}$ human pancreatic carcinoma cells. Pancreas 6:142-149

43. Coffey RJ, Derynck R, Wilcox JN, Bringman TS, Goustin AS, Moses HL, Pittelkow MR 1987 Production and autoinduction of transforming growth factor- $\alpha$ in human keratinocytes. Nature 328:817-820

44. Raja RH, Paterson AJ, Shin TH, Kudlow JE 1991 Transcriptional regulation of the human transforming growth factor- $\alpha$ gene. Mol Endocrinol 5:514520

45. Mulder KM 1991 Differential regulation of c-myc and transforming growth factor- $\alpha$ messenger RNA expression in poorly differentiated and well-differentiated colon carcinoma cells during establishment of a quiescent state. Cancer Res 51:2256-2262

46. Korc M, Chandrasekar B, Shah GN 1991 Differential binding and biological activities of epidermal growth factor and transforming growth factor $\alpha$ in a human pancreatic cancer cell line. Cancer Res 51:6243-6249

47. Ménard D, Pothier P 1991 Radiographic localization of epidermal growth factor receptors in human fetal gut. Gastroenterology 101:640-649

48. Walker-Smith JA, Phillips AD, Walford N, Gregory H, Fitzgerald JD MacCullagh K, Wright NA 1985 Intravenous epidermal growth factor/urogastrone increases small-intestinal cell proliferation in congenital microvillous atrophy. Lancet 2:1239-1240 